\title{
Psychometric properties of the Polish version of the Self-Concept Clarity Scale (SCCS)
}

\author{
Hubert Suszek ${ }^{1 \cdot A, B, D, E, F, G}$, Krzysztof Fronczyk $^{1 \cdot C, E}$, Maciej Kopera ${ }^{2 \cdot D, E}$, Norbert Maliszewski ${ }^{3 \cdot E}$, \\ Ewa Agnieszka Eyś ${ }^{1 \cdot E}$ \\ 1: University of Warsaw, Poland \\ 2: Medical University of Warsaw, Poland \\ 3: Cardinal Stefan Wyszyński University in Warsaw, Poland
}

\section{BACKGROUND}

Self-concept clarity is one of the features describing the structural aspect of the self. It refers to the extent to which the contents of an individual's self-concept are clearly and confidently defined, internally consistent, and temporally stable. The aim of the study was to translate and evaluate the psychometric properties of the Polish version of the Self-Concept Clarity Scale (SCCS).

\section{PARTICIPANTS AND PROCEDURE}

A total of 2507 graduates and undergraduates participated in the study. Their ages ranged from 18 to 70 years $(M=24.74$, $S D=23.00) ; 66 \%$ of them were female. The Polish version of the SCCS was developed using the back-translation method. The SCCS was administered along with measures of sense of self (Sense of Self Scale), self-esteem (Rosenberg Self-Esteem Scale), psychological distress (Goldberg General Health Questionnaire), personality (NEO-Five Factor Inventory), and social desirability (Marlowe-Crowne Social Desirability Scale).

\section{RESULTS}

The factor structure, reliability, and validity of the scale was investigated. Results from exploratory and confirmatory factor analysis showed a one-factor solution. Internal reliability and test-retest reliability was high. Significant relations between SCCS and weak sense of self, self-esteem, psychological distress, personality, and social desirability supported its convergent validity.

\section{CONCLUSIONS}

This study demonstrated that the Polish version of the SCCS is a reliable and valid self-report measure for the self-concept clarity.

\section{KEY WORDS}

Self-Concept Clarity Scale; Polish version; self-concept

Corresponding AUthor - Hubert Suszek, Ph.D., Faculty of Psychology, University of Warsaw, 5/7 Stawki Str., 00-183 Warsaw, Poland, e-mail: hubert.suszek@psych.uw.edu.pl

AUthors' CONTRIBUtions - A: Study design · B: Data collection $\cdot$ C: Statistical analysis $\cdot$ D: Data interpretation E: Manuscript preparation · F: Literature search · G: Funds collection

to CITE this ARTICle - Suszek, H., Fronczyk, K., Kopera, M., Maliszewski, N., \& Łyś, E. A. (2018). Psychometric properties of the Polish version of the Self-Concept Clarity Scale (SCCS). Current Issues in Personality Psychology 6(3), 181-187. RECEIVED 24.01.2018 · REVIEWED 05.04.2018 · ACCEPTED 07.05.2018 · PUBLISHED 10.07.2018 


\section{BACKGROUND}

There is agreement among different authors on the distinction between the content and structural aspects of the self-concept (Campbell et al., 1996). The content aspect refers to an individual's conceptions of who or what he or she is and feelings towards oneself. The structural aspect of the self refers to how the contents of the self are organised. Examples of variables that tap the structure of the self-concept are self-complexity (Linville, 1985), which represents the number of distinct dimensions that underlie the organisation, self-concept differentiation (Donahue, Robins, Roberts, \& John, 1993), which has been defined as the degree to which one sees the self as having different personality characteristics in different social roles, and self-discrepancies (Higgins, 1987), which refer to inconsistencies between individuals' beliefs about their traits and various internalised standards. Campbell et al. (1996) proposed focusing on another property of self-structure: self-concept clarity. They defined it as "the extent to which the contents of an individual's self-concept are clearly and confidently defined, internally consistent, and temporally stable" (p. 141). In a recent overview of research on self-concept clarity DeMarree and Lodi-Smith (2018) concluded that, to date, theory on self-concept clarity has been relatively limited. However, they admit that the construct is highly recognisable with over 1300 citations as of 2017, according to Google Scholar. The authors also specified distinct compounds of the definition of self-concept clarity. First, self-concept clarity refers to self-conceptions rather than self-esteem. Second, self-concept clarity does not refer to a specific self-conception domain or self-belief but to the whole of one's self-concept. Third, it also points to four dimensions of this variable: clarity, confidence, internal consistency, and temporal stability. It seems that self-concept clarity addresses an important universal question: To what extent do people truly know themselves?

Campbell et al. (1996) developed a 12-item self-report instrument (the Self-Concept Clarity Scale) for measuring self-concept clarity. The scale was shown to have good psychometric properties in terms of internal consistency (.86) and test-retest reliability (.75); the scale displayed a unidimensional factor structure.

A few studies have explored the relationship between self-concept clarity and other relevant constructs. It was shown that low self-concept clarity was associated with high neuroticism and low conscientiousness (Campbell et al., 1996; Campbell, Assanand, \& Di Paula, 2003; Matto \& Realo, 2001). It also correlated positively with various measures of well-being and adjustment measures such as anxiety or depression (Bigler, Neimeyer, \& Brown, 2001;
Campbell et al., 1996; Wu \& Watkins, 2009). The correlate of self-concept clarity that is most frequently reported is self-esteem. Several studies have shown moderate to high correlations between both variables, indicating that people with higher self-esteem report more clear self-concepts (Bechtoldt, De Dreu, Nijstad, \& Zapf, 2010; Campbell et al., 1996, 2003; Lewandowski, Nardone, \& Raines, 2010; Matto \& Realo, 2001; Stucke, 2002; Vartanian, 2009; Wu \& Watkins, 2009).

The Self-Concept Clarity Scale has been translated into several languages and adapted for different cultures, including Korean (Kim, 1998), Japanese (Tokunaga \& Horiuchi, 2012), Slovak (Fickova, 1999), Estonian (Matto \& Realo, 2001), and German (Stucke, 2002). The adaptations provided evidence for generalisability of the self-concept clarity construct across different languages and cultures.

The aim of the current study was to develop a Polish version of the SCCS. We expected that the Polish version would display similar properties to the original scale; it was expected to replicate a one-factor solution. To support its convergent validity, we also hypothesised that self-concept clarity would be related to other measures: weak sense of self, self-esteem, psychological distress, personality, and social desirability.

\section{PARTICIPANTS AND PROCEDURE}

\section{PARTICIPANTS}

A total of 2507 graduates and undergraduates of the University of Warsaw participated in the study. Their ages ranged from 18 to 70 years $(M=24.74$, $S D=23.00)$; $66 \%$ of them were female. No participants received compensation for their participation.

\section{MEASURES}

The Polish version of the SCCS was developed using the back-translation method. First, the original version was translated into Polish by a professional translator, then it was back-translated by a second translator to ensure comparability and equivalence in meaning. Neither of the translators was aware of the content of this study. Discrepancies were discussed and agreed upon by both the authors and the back-translator. The Polish version of the SCCS comprises 12 items, which participants respond to on a five-point Likert scale: from 1 - strongly disagree to 5 - strongly agree. The result scores range from 12 to 60 , with higher scores indicating higher self-concept clarity.

Sense of Self Scale. Sense of self was measured with the 12-item Sense of Self Scale - SOSS (DratRuszczak \& Niemyjska, 2013; Flury \& Ickes, 2007). 
The SOSS was designed to assess four components of a weak sense of self: 1) lack of understanding of oneself; 2) sudden shifts in feelings, opinions, and values; 3) tendency to confuse one's feelings, thoughts, and perspectives with those of others; and 4) feeling that one's very existence is tenuous. Reliability in this study was .87 .

Rosenberg Self-Esteem Scale. Self-esteem was measured with the 10-item Rosenberg Self-Esteem Scale SES (Łaguna, Lachowicz-Tabaczek, \& Dzwonkowska, 2007; Rosenberg, 1965). The SES is a one-dimensional self-report scale that measures global self-worth by measuring both positive and negative feelings about the self. In the present study, the reliability of the observed scores was 85 .

Goldberg General Health Questionnaire. Psychological distress was assessed with the 12-item Goldberg General Health Questionnaire - GHQ-12 (Goldberg \& Williams, 1988; Makowska \& Merecz, 2001). The GHQ-12 is a brief self-administered measure of current mental health (psychological distress), which was designed as a unidimensional scale. The patient is asked to assess changes in his/her mood, feelings, and behaviours within the period of the past four weeks. The Cronbach 's $\alpha$ for the GHQ-12 in this study was .80 .

NEO-Five Factor Inventory. The Big Five personality traits were measured with the 60-item NEO-Five Factor Inventory - NEO-FFI (Costa \& McCrae, 1992; Zawadzki, Strelau, Szczepaniak, \& Śliwińska, 1998). The NEO-FFI is a general self-report measure of personality reflecting the dimensions of the five-factor model: neuroticism, extraversion, openness to experience, conscientiousness, and agreeableness. The internal consistency in this study was between .71 and .86 .

Marlowe-Crowne Social Desirability Scale. Social desirability was assessed with the 33-item Marlowe-Crowne Social Desirability Scale - MCSD (Crowne \& Marlowe, 1960; Siuta, 1989). The MCSD is designed to assess the extent to which people describe themselves in favourable terms. The reliability of the scale in this study was .75.

All participants filled in the Polish version of the SCCS, and different subsamples of the entire sample additionally filled in one of the above-mentioned instruments: SOSS $(N=225)$, SES $(N=403)$, GHQ-12 $(N=214)$, NEO-FFI $(N=51), \operatorname{MCSD}(N=127)$.

\section{RESULTS}

Table 1 presents the basic descriptive statistics for the total score of the SCCS. According to Curran, West, and Finch (1996), for univariate normality, skewness and kurtosis values of 0-2 and 0-7, respectively, can be taken as demonstrating sufficient normality. Based on the values shown in Table 1 , the data appear to show sufficient normality.

\section{FACTOR ANALYSIS}

We conducted an exploratory factor analysis. The scree plot of this analysis is presented in Figure 1. It is clear that one component emerged. The obtained factor explains about $40 \%$ of variance with an eigenvalue equal to 4.82 . The eigenvalue of the second factor was below 1 . Such a result clearly supports the one-factor solution. Table 2 shows factor loadings and communalities of the SCCS items. All item loadings were positive and high or moderate. Confirmatory factor analysis (CFA) was conducted to further test the one-factorial model of the SCCS items. The parcelling method was used in the CFA model. In this method, the means of groups of items were introduced as observable variables (Williams \& O'Boyle, 2008). The SCCS items were randomly divided into four parcels, each consisting of three items. Table 3 lists the factor loadings that were obtained. Based on the indicators and recommendations of Kenny and McCoach (2003) in Table 4, the CFA model of the SCCS is acceptable.

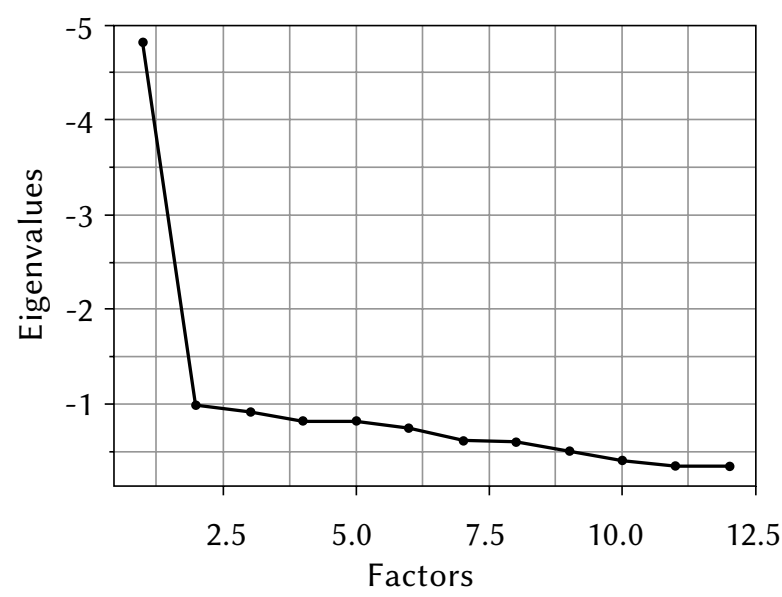

Figure 1. Scree plot of exploratory factor analysis of SCCS items.

Table 1

Descriptive statistics of SCCS score distribution

\begin{tabular}{cccccc}
\hline$M$ & Median & Variance & $S D$ & Skewness & Kurtosis \\
\hline 39.75 & 41.00 & 98.33 & 9.92 & -0.22 & -0.56 \\
\hline
\end{tabular}


Table 2

Factor loadings, communalities of the SCCS items, and corrected item-total correlations

\begin{tabular}{|c|c|c|c|c|}
\hline \multicolumn{2}{|c|}{ Item } & \multirow{2}{*}{$\begin{array}{l}\text { Loadings } \\
.70\end{array}$} & \multirow{2}{*}{$\begin{array}{c}\text { Communalities } \\
.49\end{array}$} & \multirow{2}{*}{$\begin{array}{r}\text { Item-total } \\
\text { correlation } \\
.64\end{array}$} \\
\hline 1. & $\begin{array}{l}\text { Moje przekonania na swój temat często są } \\
\text { sprzeczne jedne z drugimi* }\end{array}$ & & & \\
\hline 2. & $\begin{array}{l}\text { Jednego dnia mogę mieć jakąś opinię o sobie, } \\
\text { a drugiego dnia odmienną* }\end{array}$ & .73 & .53 & .63 \\
\hline 3. & $\begin{array}{l}\text { Spędzam dużo czasu na zastanawianiu się, } \\
\text { jakiego rodzaju osobą rzeczywiście jestem* }\end{array}$ & .62 & .39 & .57 \\
\hline 4. & $\begin{array}{l}\text { Czasem czuję, że nie jestem w rzeczywistości } \\
\text { osobą, którą wydaję się być }^{*}\end{array}$ & .69 & .48 & .65 \\
\hline 5. & $\begin{array}{l}\text { Kiedy myślę o sobie z przeszłości, nie jestem } \\
\text { pewien, jaki naprawdę byłem* }\end{array}$ & .53 & .29 & .50 \\
\hline 6. & $\begin{array}{l}\text { Rzadko doświadczam konfliktów pomiędzy } \\
\text { różnymi stronami mojej osobowości }\end{array}$ & .37 & .14 & .35 \\
\hline 7. & $\begin{array}{l}\text { Czasami myślę, że znam innych ludzi lepiej } \\
\text { niż samego siebie* }\end{array}$ & .49 & .24 & .46 \\
\hline 8. & $\begin{array}{l}\text { Moje przekonania na temat samego siebie } \\
\text { wydają się zmieniać bardzo często* }\end{array}$ & .71 & .51 & .69 \\
\hline 9. & $\begin{array}{l}\text { Gdyby poproszono mnie o opisanie swojej } \\
\text { osobowości, mój opis mógłby różnić się z dnia } \\
\text { na dzień* }\end{array}$ & .76 & .57 & .68 \\
\hline & $\begin{array}{l}\text { Nawet gdybym chciał, nie sądzę, żebym potrafił } \\
\text { opowiedzieć komuś, jaki naprawdę jestem* }\end{array}$ & .53 & .28 & .50 \\
\hline & $\begin{array}{l}\text { Ogólnie mam jasne poczucie tego, kim i czym } \\
\text { jestem }\end{array}$ & .38 & .14 & .38 \\
\hline 12. & $\begin{array}{l}\text { Często trudno jest mi zdecydować się na coś, } \\
\text { ponieważ tak naprawdę nie wiem, czego chcę }\end{array}$ & .41 & .17 & .39 \\
\hline
\end{tabular}
Note. ${ }^{*}$ Reverse-keyed item.

Table 3

Factor loadings of the parcels

\begin{tabular}{lcccc}
\hline Parcel & Raw value & Raw SE & Std. value & Std. SE \\
\hline Parcel 1 & 2.68 & 0.06 & 0.81 & 0.01 \\
Parcel 2 & 2.22 & 0.05 & 0.76 & 0.01 \\
Parcel 3 & 2.39 & 0.06 & 0.77 & 0.01 \\
Parcel 4 & 1.76 & 0.06 & 0.61 & 0.02 \\
\hline
\end{tabular}

Table 4

Fit statistics for SCCS

\begin{tabular}{cccccccc}
\hline$\chi^{2}$ & $d f$ & $p$ & AIC & BIC & CFI & TLI & RMSEA \\
\hline 30.98 & 2 & $<.001$ & 46.983 & 93.725 & 0.992 & 0.977 & 0.075 \\
\hline
\end{tabular}




\section{PSYCHOMETRIC PROPERTIES}

Reliability of the scale scores was evaluated using two techniques. Internal consistency reliability was estimated using Cronbach's $\alpha$ coefficient. This index was .86 , and boundaries of $95 \%$ confidence were .84 and .87 . In addition, test-retest reliability was evaluated by re-administering the SCCS to 88 randomly selected participants one month after the initial administration. The estimated reliability was $.87, p<.001$. These two estimations of reliability are of almost the same magnitude and are quite high.

The corrected (for overlap) item-scale correlations were found to be substantial (Table 2). The median item-scale correlation was .54. All of these correlations highly exceeded the value of 0.20 , which is the limit value of item acceptability.

\section{CORRELATES BETWEEN THE SCCS AND THE OTHER RELEVANT MEASURES}

The SCCS was strongly negatively correlated with the sense of self $(r=-.71, p<.001)$. This means that people lower in self-concept clarity had a weaker sense of self. It was also found that the SCCS was moderately correlated with the measure of self-esteem $(r=.39, p<.001)$, which shows that people higher in clarity had higher self-esteem. Psychological distress correlated moderately negatively with the $\operatorname{SCCS}(r=-.33, p<.001)$. Only two correlations with personality dimensions were significant. The SCCS was strongly negatively correlated with neuroticism $(r=-.56, p<.001)$ and moderately positively with conscientiousness $(r=.30, p=.036)$, thus indicating that people higher in self-concept clarity were less neurotic and more conscientious. The correlation of SCCS with social desirability was moderate $(r=.39$, $p<.001)$.

\section{DISCUSSION}

The aim of our study was to validate the Polish version of the SCCS. We examined its psychometric properties and its relations with the measures of other traits. We also checked its temporal stability. The psychometric properties of the SCCS were shown to be similar to the original English version. The results from exploratory and confirmatory factor analysis showed a one-factor solution. Both internal consistency and temporal stability were high.

Correlations with other measures support the construct validity of the SCCS. The most important evidence comes from the strong correlation that the SCCS exhibited with the sense of self scale. The sense of self seems to be an overlapping construct to some extent; however, it is not simply redundant with the sense of self per se. According to the authors, the construct is much broader (Flury \& Ickes, 2007). It emerged from the study of borderline personality disorder but was designed to go beyond this clinical syndrome to explore healthy individuals who have a weak versus strong sense of self. It contains four components: 1) lack of understanding of oneself; 2) sudden shifts in feelings, opinions, and values; 3) tendency to confuse one's feelings, thoughts, and perspectives with those of others; and 4) feeling that one's very existence is tenuous. It seems that only the first component corresponds directly to the clarity of self-concept.

It was also found that the SCCS was moderately correlated with the measure of self-esteem. This result is congruent with other studies which show that people with low self-esteem have more poorly articulated notions of who or what they are (Campbell et al., 1996). It is also congruent with older studies showing that people with low self-esteem have a more diffused identity and lower ego strength (Block, 1961; O’Brien \& Epstein, 1988).

Also supportive for the validity of SCCS is the observed connection with psychological distress, neuroticism, and conscientiousness. The results indicate that people higher in self-concept clarity are less neurotic, more conscientious, and have less psychological distress, which is consistent with previous studies. Both Campbell et al. (1996) and Matto and Realo (2001) found the SCCS to be moderately and negatively correlated with neuroticism and moderately positively correlated with consciousness. These traits probably play a causal role in the development and maintenance of a stable self-concept.

We found a significant correlation of the SCCS with social desirability. The magnitude of this correlation is very similar to that obtained by Campbell et al. (1996) and Wu and Watkins (2009). This result suggests that the SCCS is quite free from the social desirability response bias that may confound many self-concept measures.

Some limitations of this study need to be noted. First, the present study relied on very few adjustment measures. In particular, psychological distress was measured with the GHQ-12, which is a short global measure. Further research is necessary to consider various dimensions of psychological distress. Second, this study examined a non-clinical sample, which limits the generalisability of the findings. The choice of a healthy population may underestimate the relevance of the clarity of the self-concept in psychopathological symptoms. It may be important for future researchers to extend the study by examining clinical populations that are theoretically prone to inconsistency and instability of self-concept, e.g. persons with borderline or narcissistic personality disorder. 


\section{ACKNOWLEDGMENTS}

We thank Jennifer D. Campbell for her permission to adapt the SCCS into Polish.

\section{References}

Bechtoldt, M. N., De Dreu, C. K. W., Nijstad, B. A., \& Zapf, D. (2010). Self-concept clarity and the management of social conflict. Journal of Personality, 78, 539-574. DOI: 10.1111/j.14676494.2010.00626.x

Bigler, M., Neimeyer, G. J., \& Brown, E. (2001). The divided self revisited: Effects of self-concept clarity and self-concept differentiation on psychological adjustment. Journal of Social and Clinical Psychology, 20, 396-415. DOI: 10.1521/ jscp.20.3.396.22302

Block, J. (1961). Ego identity, role variability, and adjustment. Journal of Consulting Psychology, 25, 392-397. DOI: 10.1037/h0042979

Campbell, J. D., Assanand, S., \& Di Paula, A. (2003). The structure of the self-concept and its relation to psychological adjustment. Journal of Personality, 71, 115-140. DOI: 10.1111/1467-6494.t01-1-00002

Campbell, J. D., Trapnell, P. D., Heine, S. J., Katz, I. M., Lavallee, L. F., \& Lehman, D. R. (1996). Self-concept clarity: Measurement, personality correlates, and cultural boundaries. Journal of Personality and Social Psychology, 70, 141-156. DOI: 10.1037/00223514.70.1.141

Costa, P. T. Jr., \& McCrae, R. R. (1992). Revised NEO Personality Inventory (NEO-PI-R) and NEO Five-Factor Inventory (NEO-FFI) professional manual. Odessa: Psychological Assessment Resources.

Crowne, D., \& Marlowe, D. (1960). A new scale of social desirability independent of psychopathology. Journal of Consulting Psychology, 24, 349-354. DOI: 10.1037/h0047358

Curran, P. J., West, S. G., \& Finch, J. F. (1996). The robustness of test statistics to nonnormality and specification error in confirmatory factor analysis. Psychological Methods, 1, 16-29. DOI: 10.1037//1082-989x.1.1.16

DeMarree, K. G., \& Lodi-Smith, J. (2018). An overview of self-concept clarity: Definitions, empirical themes, and introduction to the volume. In J. Lodi-Smith \& K. G. DeMarree (eds.), Self concept clarity: Perspectives on assessment, research, and application (pp. 12-20). New York: Springer.

Donahue, E. M., Robins, R. W., Roberts, B. W., \& John, O. P. (1993). The divided self: Concurrent and longitudinal effects of psychological adjustment and social roles on self-concept differentiation. Journal of Personality and Social Psychology, 64, 834-846. DOI: 10.1037/0022-3514.64.5.834
Drat-Ruszczak, K., \& Niemyjska, A. (2013). Polska adaptacja skali Ja (SOSS) [Polish adaptation of Sense of Self Scale (SOSS)]. Sopot: SWPS.

Fickova, E. (1999). Personality dimensions and self-esteem indicators relationships. Studia Psychologica, 41, 323-328.

Flury, J. M., \& Ickes, W. (2007). Having a weak versus strong sense of self: The sense of self scale (SOSS). Self and Identity, 6, 281-303. DOI: 10.1080/15298860601033208

Goldberg, D. P., \& Williams, P. (1988). A user's guide to the General Health Questionnaire. Windsor, UK: NFER-Nelson.

Higgins, E. T. (1987). Self-discrepancy: A theory relating self and affect. Psychological Review, 94, 319340. http://dx.doi.org/10.1037//0033-295x.94.3.319

Kenny, D. A., \& McCoach, D. B. (2003). Effect of the number of variables on measures of fit in structural equation modeling. Structural Equation Modeling: A Multidisciplinary Journal, 10, 333-351. DOI: $10.1207 /$ s15328007sem1003_1

Kim, D. (1998). Self-concept clarity in Korea: Personality, self-consciousness and behavioural correlates. Chung-Ang University, Seoul, South Korea.

Lewandowski, G. W., Nardone, N., \& Raines, A. J. (2010). The role of self-concept clarity in relationship quality. Self and Identity, 9, 416-433. DOI: 10.1080/15298860903332191

Linville, P. W. (1985). Self-complexity and affective extremity: Don't put all of your eggs in one cognitive basket. Social Cognition, 3, 94-120. DOI: 10.1521/soco.1985.3.1.94

Łaguna, M., Lachowicz-Tabaczek, K., \& Dzwonkowska, I. (2007). Skala samooceny SES Morrisa Rosenberga - polska adaptacja metody [The Rosenberg Self-Esteem Scale: Polish adaptation of the scale]. Psychologia Spoteczna, 2, 164-176.

Makowska, Z., \& Merecz, D. (2001). Polska adaptacja kwestionariuszy ogólnego stanu zdrowia Davida Goldberga: GHQ-12 i GHQ-28 [Polish adaptation of Goldberg's General Health Questionnaires: GHQ-12 and GHQ-28]. In M. Makowska \& D. Merecz (eds.), Ocena zdrowia psychicznego na podstawie badań kwestionariuszami Davida Goldberga [The assessment of mental health using Golberg's questionnaires] (pp. 191-264). Łódź: Instytut Medycyny Pracy im. Prof. J. Nofera.

Matto, H., \& Realo, A. (2001). The Estonian Self-Concept Clarity Scale: psychometric properties and personality correlates. Personality and Individual Differences, 30, 59-70. DOI: 10.1016/S01918869(00)00010-6

O’Brien, E. J., \& Epstein, S. (1988). MSEI: the Multidimensional self-esteem inventory: professional manual. Odessa, Fla.: Psychological Assessment Resources, Inc.

Rosenberg, M. (1965). Society and the adolescent self-image. Princeton, NJ: Princeton University Press. 
Siuta, J. (1989). Zmienna aprobaty społecznej w badaniach nad zjawiskami hipnotycznymi [Social desirability in research on hypnotic phenomena]. Zeszyty Naukowe Uniwersytetu Jagiellońskiego, 884, 131-141.

Stucke, T. S. (2002). Überprüfung einer deutschen Version der Selbstkonzeptklarheits-Skala von Campbell [Validity of Campbell's Self-Concept Clarity Scale]. Zeitschrift für Differentielle und Diagnostische Psychologie, 23, 475-484. DOI: 10.1024//0170-1789.23.4.475

Tokunaga, Y., \& Horiuchi, T. (2012). Development of a Japanese version of the Self-Concept Clarity (SCC) Scale. The Japanese Journal of Personality, 20, 193-203. DOI: 10.2132/personality.20.193

Vartanian, L. R. (2009). When the body defines the self: self-concept clarity, internalization, and body image. Journal of Social and Clinical Psychology, 28, 94-126. DOI: 10.1521/jscp.2009.28.1.94

Williams, L. J., \& O’Boyle, E. H. (2008). Measurement models for linking latent variables and indicators: A review of human resource management research using parcels. Human Resource Management Review, 18, 233-242. DOI: 10.1016/j. hrmr.2008.07.002

Wu, J., \& Watkins, D. (2009). Development and validation of a Chinese version of the Self-Concept Clarity Scale. Psychologia, 52, 67-79. DOI: 10.2117/ psysoc.2009.67

Zawadzki, B., Strelau, J., Szczepaniak, P., \& Śliwińska, M. (1998). Inwentarz osobowości NEO-FFI Costy i McCrae. Polska adaptacja [Polish adaptation of Costa and McCrae's NEO-FFI Personality Inventory]. Warsaw: Pracownia Testów Psychologicznych PTP. 